\title{
Development of Taiwan College Students' Sense of Life Meaning Scale
}

\author{
Wu Ho-Tang ${ }^{1}$, Chou Mei-Ju, ${ }^{2, *}$, Lei Meng-Shan ${ }^{3}$, Hou Jing-Fang ${ }^{4}$, Wu Ming-Hsyang ${ }^{5}$ \\ ${ }^{1}$ Department of Education, National Kaohsiung Normal University, Taiwan \\ ${ }^{2}$ Early Childhood Education and Center for Teacher Education, National Pingtung University, Taiwan \\ ${ }^{3}$ Department of Education, National Kaohsiung Normal University, Taiwan \\ ${ }^{4}$ Kaohsiung Municipal Guochang Junior High School, Taiwan \\ ${ }^{5}$ Department of Hotel and Restaurant Management, National Pingtung University of Science and Technology, Taiwan
}

Copyright (C) 2015 by authors, all rights reserved. Authors agree that this article remains permanently open access under the terms of the Creative Commons Attribution License 4.0 International License

\begin{abstract}
The research aims to develop "Sense of Life Meaning Scale" of Taiwan college students. In accordance with the related literature, most Western scholars adopted Frankl's Logotherapy for developing "Sense of Life Meaning Scale", which consists of freedom of will, will to meaning and meaning of life. The research also adopts these three beliefs as research factors; furthermore, with the related literature and measurements, 20-items questionnaire was designed. Owing to the past instrument have already proved the existence of three factors within sense of life meaning, CFA was directly applied for the research. This part is categorized into three models: (1) The initial model: the result reveals that two items' factor loadings are under .55., and need to be delete. (2) The modified model: After deleted two items, the model retested, and reveal firstly, the whole applicableness is acceptable; secondly, item quality test isn't under the situation of offending estimates (it means all output data are in an acceptable range); thirdly, internal construct applicableness analysis consisting of component reliability, average variance extracted; AVE ( $\rho v)$, competitive model comparison, and sex-group measurement identity test all qualified. (3) Cross-validity model: For the modified model, the research investigate another samples $(N$ $=405$ ), and after the re-verification, the outcome present acceptable whole applicableness. Therefore, the three factors 18 item scale of "Sense of Life Meaning" is built.
\end{abstract}

Keywords Sense of Life Meaning, Logotherapy, CFA

\section{Introduction}

Sense of life meaning means the consistence among the pursuit and the realization of goal and its joyfulness after accomplishment(Reker, 2000) [1]. Dezutter et al(2014) [2] proposed that meaning in life is an important correlate of health and well-being. Possessing meaning in life is essential to human functioning(Waytz, Hershfield, \& Tamir, 2015) [3], for the meaning of life lies in the pursuit of meaning, it makes people being aware of self-existence and value(Csíkszentmihályi, 2008) [4]. Therefore, when life has its meaning, people will have the ability and the goal to live (Frankl, 1984) [5].

As for the design of sense of life meaning scale, foreign scholars starts early. Crumbaugh \& Maholick's (1964) [6] designed the Purpose in Life Test [PIL]. Later on, quite a few related scales have been developed. In researching data in Taiwan area, the scholar Ho(1987) [7] published the research on College Students' Meaning of Life and Its Correlates: An Empirical Study of the Concept of Logotherapy. Its research samples were 873 college students, and analyzed the relationship among sense of life meaning, responsibility, self-advancement, time awareness. The sense of life meaning adopted Crumbaugh \& Maholick's (1964) [6] designed the Purpose in Life Test [PIL] to realize individual awareness for his/her life purpose and meaning. Results revealed that one-fourth college students feel that they are lacking of life purpose and meaning. For it is the research 28 years ago, for the development and advancement in political, social, education, technology, industry, and economics in Taiwan, the recent situation of modern college students must have different thoughts on their sense of life meaning. For the validity of Ho(1990) [8]'s Life Attitude Profile has its significance; however, with the difference of times, the revised scale needs to be in the same pace of the current situation in accordance with modern education society circumstances.

Furthermore, the searching for meaning within Frankl's reference logotherapy belongs to the third school of Viennese Psychology(Gould,1993) [9]; the second school of Viennese Psychology lies on Adler's searching for power; the first one is Freud's searching for pleasure. That is to say, Frankl's theory in scholar is very important and influential. As illustrated in Table 1, the scale design of life meaning is based on Frankl's Logotherapy, and the research also follows this pattern to apply the practice of Frankl's Logotherapy. 


\section{Related Literature}

\section{Basic Belief of Logotherapy}

From Table 1, Frankl's Logotherapy serves as the important theoretical basis for sense of life meaning scale. Its theory emphasizes on individual's efforts in searching for life meaning after his/her confrontation toward death, isolation and meaninglessness (Corey, 2012) [10]. Frankl(1967, 1988) [11][12] proposed that there are three interrelated basic belief within Logotherapy.

\section{Freedom of Will}

Freedom of Will means the attitude the individual chooses to face Frankl [11] [12] [13]clearly points out three unavoidable existential problems. 1.) suffering : Starck [14] suggests that suffering belongs a very painful situation. Life meaning could be elaborated from many perspectives, in this research, there are three dimensions, including suffering, death, and guilt. , 1) firstly, people have sufferings in daily life, and no matter how terrible it is, after we truly face the essence of terrible situation, we gain life meaning itself. 2.) death: the fear for death is derived from individual's unable to find out meaningful life (Wong, Reker, \& Gesser, 1994) [15]. With the experimenting of life limitation and death itself, life itself becomes meaningful. 3.) guilty : in accordance with Frank1(1967) [11], he proposed that any individual has to be responsible for his or her personal choices. Generally, individual feels guilty for his/her not being honest in facing life; however, with self-reflection, examination, and facing truth, individual transform himself into the level in creating meaningful life.

\section{Will to Meaning}

In accordance with Frankl, the description of the will to meaning is that individual makes his/her life experience more meaningful and with it to find out the primary motivation of life purpose (Starck, 2008) [16]. For this belief is the central core theory concept of Logotherapy (Frankl, 1988) [12]. Because life meaning is decided for individual's involving into its degree (Hartman \& Zimberoff, 2003) [14], when will to meaning is frustrated, people would feel bored and have suspicion toward life, the so called existential vacuum, which further excite existential frustration (Frankl, 1984) [5].

\section{Meaning of Life}

Frankl(1986) [17] proposed that the primary premise of searching for life meaning is looking for life purpose, and Frankl(1967) [11] had already suggested that with creative values, experiential values, and attitudinal values, the above three access lead to life meaning. Breitbart(2001) [18] believed that the following three elements are the primary source of life meaning: 1.) the creative value of work, deeds, and dedication to causes; 2.) The experiment of art, nature, humor, love, relationship, role...etc; 3 .) Individual's attitude toward the suffering and existence problem needs to be consistent.

\section{The Measurement of Life Meaning}

This study aims to compile a life meaning scale for university student. Therefore, in the beginning we analyzed the status domestic and foreigner academy is doing on compilation as our reference, and organized relevant life meaning scales in Table.1.

From Table 1, Frankl's theory of Logotherapy, three beliefs including freedom of will, will to meaning, and meaning of life provide the basis for the scale development of sense of life meaning. From the measurement from table 1, in order to develop scale, it emphasized on single primary belief. For example, Starck's MIST (1985) [26], it measures the concept of adult's unavoidable sufferings ; The PIL by Crumbaugh and Maholick (1964) [6], SONG by Crumbaugh (1977) [22], Wong (1998) [28]'s PMP on measuring the will to meaning. The LPQ made by Hablas, Hutzell(1980) [24] and Steger (2006) [21] is to measure the level adult find life meaning and purpose. There is also measurement for all three beliefs, such as Jonsén et al (2010) [30], since Frankl considered that meaning in life comprises three dimensions; freedom of will, will to meaning, meaning in life (Jonsén et al., 2010) [30], the Swedish life meaning scale compiled by Jonsén et al can be divided into three major aspects such as the freedom of life meaning, the will to seek life meaning and the meaning of existing in the world which will all meet the three major beliefs of logotherapy. The following three beliefs are illustrated.

First, since the three major beliefs of Frankl's logotherapy theory is the theoretical foundation for developing life meaning scale, this study also adopted it.

Second, the topic of scale in Table.1 also provides a reference for this study to compile a scale. For example, as to the first draft of questionnaire on aspect of freedom of will in this study, except according to the three unavoidable problems as foundation such as misery, death and guilt, this study also referred to scales specialized to measure misery, like Starck (1985) [26]'s MIST, or LAP by Reker \& Peacock(1981) [25] which is regarding to aspect of life control and death acceptance. As to the first draft on aspect of will to meaning, except above theoretical foundation, this study also referred to Ho(1990) [8]'s life attitude profile, PIL by Crumbaugh \& Maholicks (1964) [6], Crumbaugh(1977) [22]'s SONG, Shek(1988) [27]'s Purpose in life questionnaire, LAP by Reker \& Peacock(1981) [25], PIL compiled by Dirksen(1995) [32], Wong(1998) [28]'s PMP and the MLQ-S compiled by Steger(2006) [21] and so on. 
Table 1. The Related Literature of the Sense of Life Meaning Scale Table

\begin{tabular}{|c|c|c|c|c|}
\hline Designer & Instrument & Theoretical Basis & Purpose & Dimension \\
\hline $\begin{array}{c}\text { Crumbaugh \& } \\
\text { Maholick's } \\
(1964)[6]\end{array}$ & PIL & Frankl's Will to Meaning & $\begin{array}{l}\text { To measure adult's will } \\
\text { in purchasing meaning }\end{array}$ & $\begin{array}{l}20 \text { items for single dimension } \\
\text { (Schulenberg \& Melton, 2008)[19] }\end{array}$ \\
\hline $\begin{array}{l}\text { Battista \& } \\
\text { Almond } \\
(1973)[20]\end{array}$ & $\begin{array}{l}\text { Life Regard } \\
\text { Index[LRI]) }\end{array}$ & Frankl's Logotherapy & positive life regard) & $\begin{array}{l}28 \text { items, consists of framework of life } \\
\text { regard fulfillment aspects of life regard } \\
\text { two dimensions, and each dimension of } 14 \\
\text { items(Steger, Frazier, Oishi, \& Kaler, } \\
\text { 2006)[21]. }\end{array}$ \\
\hline $\begin{array}{l}\text { Crumbaugh } \\
(1977)[22]\end{array}$ & $\begin{array}{c}\text { Seeking of } \\
\text { Noetic Goals } \\
\text { Test [SONG]) }\end{array}$ & Frankl's Will to Meaning & $\begin{array}{l}\text { Measures adults' } \\
\text { motivation in pursuing } \\
\text { the meaning of life }\end{array}$ & $\begin{array}{l}20 \text { items for single dimension( Hutzell, } \\
1987)[23]\end{array}$ \\
\hline $\begin{array}{l}\text { Hablas \& Hutzell } \\
\quad(1980)[24]\end{array}$ & $\begin{array}{c}\text { Life Purpose } \\
\text { Questionnaire(L } \\
\text { PQ ) }\end{array}$ & $\begin{array}{l}\text { Transform PIL into easier } \\
\text { model }\end{array}$ & $\begin{array}{l}\text { Measures the purpose } \\
\text { of adults' finding out } \\
\text { life meaning }\end{array}$ & Single dimension \\
\hline $\begin{array}{l}\text { Reker \& Peacock } \\
\quad(1981)[25]\end{array}$ & $\begin{array}{l}\text { The Life } \\
\text { Attitude Profile } \\
\text { [LAP]) }\end{array}$ & $\begin{array}{l}\text { Crumbaugh and Maholich's } \\
\text { PIL, Crumbaugh's SONG, } \\
\text { Shostrom's Personal } \\
\text { Orientation Inventory, Lowe, } \\
\text { Gormanous, and Hubbard's } \\
\text { Death Perspective Scale, }\end{array}$ & $\begin{array}{l}\text { degree of existential } \\
\text { meaning and purpose in } \\
\text { life and the strength of } \\
\text { motivation to find } \\
\text { meaning and purpose. }\end{array}$ & $\begin{array}{l}46 \text { items , } 7 \text { dimensions, including: life } \\
\text { purpose, existential vacuum, life control, } \\
\text { death acceptance, will to meaning, goal } \\
\text { seeking, future meaning to fulfill }\end{array}$ \\
\hline $\begin{array}{c}\text { Starck } \\
(1985)[26]\end{array}$ & $\begin{array}{l}\text { Meaning in } \\
\text { Suffering Test } \\
\text { [MIST] }\end{array}$ & Frankl's Freedom of Will & $\begin{array}{l}\text { designed to measure the } \\
\text { client's perception of } \\
\text { the extent to which they } \\
\text { found meaning in } \\
\text { suffering experiences. }\end{array}$ & $\begin{array}{l}20 \text { items, consists of subjective } \\
\text { characteristics of suffering, personal } \\
\text { responses to suffering, and C meaning of } \\
\text { suffering three dimensions. }\end{array}$ \\
\hline $\begin{array}{c}\text { Shek } \\
(1988)[27]\end{array}$ & $\begin{array}{l}\text { Chinese version } \\
\text { of the Purpose in } \\
\text { Life } \\
\text { Questionnaire }\end{array}$ & Revised version of PIL & $\begin{array}{l}\text { Measuring junior high } \\
\text { school students' pursue } \\
\text { for will }\end{array}$ & $\begin{array}{c}\text { Quality of Life, Meaning of Existence, } \\
\text { Answers to Existence, Constraint of } \\
\text { Existence, and Future } \\
\text { Existence/Self-responsibility }\end{array}$ \\
\hline $\begin{array}{c}\text { Ho } \\
(1990)[8]\end{array}$ & $\begin{array}{l}\text { Life Attitude } \\
\text { Profile(LAP) }\end{array}$ & Frankl's Logotherapy & $\begin{array}{c}\text { Collects college } \\
\text { students' life attitude }\end{array}$ & $\begin{array}{l}\text { It consists of } 6 \text { dimensions: will to } \\
\text { meaning, existential vacuum, life purpose, } \\
\text { life control, suffer acceptance, and death } \\
\text { acceptance. }\end{array}$ \\
\hline $\begin{array}{c}\text { Wong } \\
(1998)[28]\end{array}$ & $\begin{array}{c}\text { Personal } \\
\text { Meaning } \\
\text { Profile[PMP]) }\end{array}$ & Frankl's Logotherapy & $\begin{array}{l}\text { intended to measure } \\
\text { people's perceptions } \\
\text { of personal meaning in } \\
\text { their lives. }\end{array}$ & $\begin{array}{c}57 \text { items, consists of seven dimensions: } \\
\text { achievement, relationship, religion, } \\
\text { self-transcendence, self-acceptance, } \\
\text { intimacy, and fair treatment or perceived } \\
\text { justice }\end{array}$ \\
\hline $\begin{array}{c}\text { Jim etc } \\
(2006)[29]\end{array}$ & $\begin{array}{l}\text { Meaning in Life } \\
\text { Scale[MiLS] }\end{array}$ & Frankl's Logotherapy & $\begin{array}{l}\text { Life Meaning for } \\
\text { Cancer's patients }\end{array}$ & $\begin{array}{l}21 \text { items, for } 4 \text { dimensions, including } \\
\text { harmony and peace, life perspective, } \\
\text { purpose and goals, confusion and lessened } \\
\text { meaning, benefits of spirituality. }\end{array}$ \\
\hline $\begin{array}{l}\text { Steger etc } \\
(2006)[21]\end{array}$ & $\begin{array}{l}\text { Meaning in Life } \\
\text { Questionnaire[M } \\
\text { LQ]) }\end{array}$ & Frankl's Life meaning & $\begin{array}{l}\text { measure of the } \\
\text { presence of, and the } \\
\text { search for, meaning in } \\
\text { life. }\end{array}$ & $\begin{array}{l}10 \text { items, two dimensions: presence of } \\
\text { meaning search for meaning. }\end{array}$ \\
\hline $\begin{array}{l}\text { Jonsén etc (2010) } \\
\qquad[30]\end{array}$ & $\begin{array}{l}\text { Swedish version } \\
\text { of the Purpose in } \\
\text { Life scale) }\end{array}$ & $\begin{array}{c}\text { PIL as a concept } \\
\text { originates from the orientation } \\
\text { of humanistic psychology } \\
\text { and is based on Frankl's } \\
\text { writings about the will to } \\
\text { meaning. }\end{array}$ & $\begin{array}{l}\text { Collecting data of life } \\
\text { purpose }\end{array}$ & $\begin{array}{l}17 \text { items, three dimensions, including: } \\
\text { meaning of existence, freedom to create } \\
\text { meaning in daily life, and will to find } \\
\text { meaning in future challenges. }\end{array}$ \\
\hline $\begin{array}{c}\text { Schulenberg \& } \\
\text { Melton } \\
(2010)[19]\end{array}$ & $\begin{array}{l}\text { Purpose in Life } \\
\text { Test }\end{array}$ & Frankl's Logotherapy & $\begin{array}{l}\text { measure of life } \\
\text { meaning }\end{array}$ & $\begin{array}{c}20 \text { items, two dimension: exciting life and } \\
\text { purposeful life }\end{array}$ \\
\hline $\operatorname{Law}(2012)[31]$ & $\begin{array}{l}\text { Purpose in Life } \\
\text { questionnaire }\end{array}$ & $\begin{array}{l}\text { Items were selected from } \\
\text { Shek's } \\
\text { (1988) Chinese version of the } \\
\text { Purpose in Life Questionnaire }\end{array}$ & $\begin{array}{l}\text { test the psychometric } \\
\text { properties of the } \\
\text { Purpose in Life for } \\
\text { early adolescence }\end{array}$ & 7 items, single dimension \\
\hline $\mathrm{Wu}(2014)[31]$ & $\begin{array}{l}\text { Teachers' Sense } \\
\text { of Life Meaning } \\
\text { Scale }\end{array}$ & Frankl's Logotherapy & $\begin{array}{l}\text { Measure teachers' life } \\
\text { meaning }\end{array}$ & $\begin{array}{l}13 \text { items, It consists of } 3 \text { dimensions: } \\
\text { freedom of will, will to meaning, meaning } \\
\text { of life }\end{array}$ \\
\hline
\end{tabular}


Third, except that the three dimension of Swedish life meaning scale just meet the three major beliefs of logotherapy, LAP by Reker \& Peacock(1981) [25] can be divided into life purpose, emptiness of existence, life control, death acceptance, will of pursuing life meaning, goal pursuing, fulfill future meaning. And these dimensions can be covered by the three major beliefs of logotherapy. Taking Ho (1990) [8] 's scale as example, existential vacuum and life purpose belong to meaning of life, life control, suffer acceptance and death acceptance belong to freedom of will.

Besides, $\mathrm{Wu}(2014)$ [33] has developed life meaning scale for Taiwanese teachers and applied CFA verification on these three beliefs, it turned out the model was fit, the result of preliminary evaluation on basic fitness was also qualified, component reliability also meet standardized value. The averaged extractions for the three latent variables all meet the standard that requires to be more than 50 . This scale shows life meaning can use the three beliefs as factors. Therefore, this scale directly adopted CFA to develop the life meaning scale for university student.

Table 2. Pre-test Questionnaire

\begin{tabular}{|c|c|c|}
\hline Dimension & Items & Code \\
\hline \multirow[t]{5}{*}{$\begin{array}{l}\text { Feedom of } \\
\text { will }(\mathrm{FW})\end{array}$} & $\begin{array}{l}\text { With attitude adjustment, crisis will } \\
\text { transform into turning point. }\end{array}$ & FW1 \\
\hline & $\begin{array}{l}\text { Frustration will make people being strong } \\
\text { and have endurance of self-growth }\end{array}$ & FW2 \\
\hline & Within difficulty, I choose to be optimistic. & FW3 \\
\hline & I will be responsible for my life choices. & FW4 \\
\hline & $\begin{array}{l}\text { After pain, I will remember the lesson to } \\
\text { avoid experiencing the same frustration. }\end{array}$ & FW5 \\
\hline \multirow{5}{*}{$\begin{array}{c}\text { Wll to } \\
\text { meaning(WM) }\end{array}$} & Without completing mission, I feel guilty. & FW6 \\
\hline & $\begin{array}{l}\text { I can face death calmly, for it is a part of } \\
\text { life. }\end{array}$ & FW7 \\
\hline & $\begin{array}{l}\text { I look for meaningful things in my life } \\
\text { continuously. }\end{array}$ & WM1 \\
\hline & $\begin{array}{l}\text { Confronting challenges in life, school, and } \\
\text { emotions, I never give up, instead, I look } \\
\text { for solutions. }\end{array}$ & WM2 \\
\hline & $\begin{array}{l}\text { I believe positive attitude will change my } \\
\text { fate. }\end{array}$ & WM3 \\
\hline \multirow{10}{*}{$\begin{array}{l}\text { Maning of } \\
\text { life(ML) }\end{array}$} & I know the life I want. & WM4 \\
\hline & I care about how to lead a meaning life. & WM5 \\
\hline & $\begin{array}{l}\text { I explore and practice my latent with } \\
\text { efforts. }\end{array}$ & WM6 \\
\hline & $\begin{array}{l}\text { I always look for the purpose of my new } \\
\text { life. }\end{array}$ & WM7 \\
\hline & $\begin{array}{l}\text { I live for my future goal (work, job, pass } \\
\text { graduate test...etc.) }\end{array}$ & ML1 \\
\hline & $\begin{array}{l}\text { I learn valuable things through everyone's } \\
\text { life experience. }\end{array}$ & ML2 \\
\hline & $\begin{array}{l}\text { I would love to give my care to people who } \\
\text { need assistance. }\end{array}$ & ML3 \\
\hline & $\begin{array}{l}\text { I realize and approve my ability from daily } \\
\text { life work and job definitely. }\end{array}$ & ML4 \\
\hline & $\begin{array}{l}\text { My life has meaning and direction with my } \\
\text { involving and practice of life ideals. }\end{array}$ & ML5 \\
\hline & $\begin{array}{l}\text { I got self-confirm and joyfulness through } \\
\text { my devoting in giving others care and } \\
\text { assistance }\end{array}$ & ML6 \\
\hline
\end{tabular}

\section{Methodology}

\section{Pretest Questionnaire}

With the development of sense of life meaning scale, the research plans the first draft from the interview with three college students. From the perspective of college students, each item was discussed and revised for the design of pre-test questionnaire. The items and numbers are shown as table 2 .

\section{Research Sampling}

As to the sampling of survey group on Sense of Life Meaning Scale, there have been two surveys:

1. The first CFA: processed as pre-examining questionnaire to complete the survey. Its model starts as an exam, and the first CFA sample is our sample to test. This time will be called as calibration sample $(N=466)$. We adopt samplings from Northern, Middle and Southern Taiwan; and for the reason of internet questionnaire delivery, so it causes the most of samples are from Northern.

2. The second CFA: we deleted two items while the first CFA of the initial model has to be amended, and after amending, there can be another batch of samples. This time will be called as validation sample $(N=405)$. We cluster samplings from Northern, Middle and Southern Taiwan areas, and in each area, one college of four grades is sampled.

Hereby the backgrounds of two kinds of sample are shown in Table.3.

Table 3. Pretest Sampling Background Arrangement of Sense of Life Meaning

Calibration Samples

\begin{tabular}{|c|c|c|c|c|c|}
\hline & & \multicolumn{2}{|c|}{$\begin{array}{c}\text { Calibration Samples } \\
(N=466)\end{array}$} & \multicolumn{2}{|c|}{$\begin{array}{c}\text { Validation Samples } \\
\qquad(N=405)\end{array}$} \\
\hline & & Numbers & Percentage & Times & Percentage \\
\hline \multirow{2}{*}{ Gender } & 1.Make & 143 & 30.7 & 114 & 28.1 \\
\hline & 2.Female & 323 & 69.3 & 291 & 71.9 \\
\hline \multirow{3}{*}{ Grade } & 1.Freshmen & 105 & 22.5 & 108 & 26.7 \\
\hline & 2.Sophomore & 100 & 21.5 & 128 & 31.6 \\
\hline & 3.Junior & 81 & 17.4 & 86 & 21.2 \\
\hline & 4.Senior & 179 & 38.4 & 83 & 20.5 \\
\hline Location & 1.North & 52 & 11.1 & 109 & 26.9 \\
\hline in & 2.Middle & 80 & 17.2 & 101 & 24.9 \\
\hline \multirow[t]{2}{*}{ Taiwan } & 3.South & 259 & 55.6 & 107 & 26.5 \\
\hline & 4.East & 75 & 16.1 & 88 & 21.7 \\
\hline
\end{tabular}

\section{Hypothesis Model}

In CFA, in accordance with Frankl's Logotherapy which adopts second-order factors model, the following three beliefs of freedom of will, will to meaning, meaning of life serve as the factor of sense of life meaning.

\section{Data Analysis}

This study focuses on the development of life meaning scale for university student, with CFA, this study test on factor structural model and whether it meets the data we 
actually collected. We processed analysis with Amos 16.0 in order to do CFA, and the test indexes are:

1. Model fit indices: we take $\chi^{2}, \mathrm{GFl}, \mathrm{TLI}, \mathrm{CFI}$ and RMSEA as our indexes to analyze if the model is appropriate.

2. Test on fitness of internal structure of model: on the test of model internal fit, we adopted four objects such as basic fit, composite reliability $(\rho c)$, average variance extracted $(\rho v)$, and construct discrimination to test.

3. Test on measurement invariance: Through the evaluation of model fit and internal fitness for model, it needs to be measurement on variance to understand if the scale is applicable to different groups. (Example: as to different genders, this study adopted Little (1997) [34] and mark up the different values between the five standardized indexes such as $\Delta \chi^{2}, \Delta \mathrm{NFI}, \Delta \mathrm{IFI}, \Delta \mathrm{RFI}$ and $\Delta \mathrm{TLI}$.). If the result of $\Delta \chi^{2}$ is not significant, and absolute value of $\Delta$ NFI, $\Delta \mathrm{IFI} 、 \Delta \mathrm{RFI} 、 \Delta \mathrm{TLI}$ is less than .05 , it means the assumption of identity is acceptable.

\section{Results}

\section{Correlation of Latent Variables}

We just added up the dimensions of life meaning and processed Pearson's product-moment correlation. The result showed that the correlation among three latent variables is between .64 to .76 and has a significant positive correlation $(p<.001)$ (See Table.4.).

Table 4. Descriptive Information and product-moment correlation of three latent factors within Sense of Life Meaning

\begin{tabular}{lccccc}
\hline \multicolumn{1}{c}{ dimensions } & 1 & 2 & 3 & $\mathrm{M}$ & $\mathrm{SD}$ \\
\hline 1.Will Freedom & 1 & & & 28.40 & 3.85 \\
2.Will for Meaning & $.68^{* * *}$ & 1 & & 27.50 & 4.38 \\
$\quad$ 3.Life Meaning & $.64^{* * *}$ & $.76^{* * *}$ & 1 & 24.69 & 3.64 \\
\hline $\begin{array}{l}N=466 . \\
* * * p<.001 .\end{array}$ & & & & & \\
\end{tabular}

From above we can know that among three latent variables of life meaning, there's a significant correlation, because freedom of will is the attitude how an individual chooses to face misery (Breitbart, 2001; Starck, 2008) [18] [16], and life has meaning under any circumstance. Facing misery, people can transform it to the achievement of life (Frankl, 1967, 1984). Which also has something to do with the meaning aspect and freedom of will aspect.

On the other hand, freedom of will emphasizes that anyone has his/her own right to choose and duty to be responsible for aftermath of their behavior. Somehow people have no choice but face the aftermath honestly makes them condemning themselves and finally transform them with more meaningful lives(Frankl, 1984) [5]. Someone who condemns his/her self is a responsible person. Therefore, they are more likely to do their best for those things haven't been completed. The will to meaning means the effort to fulfil the life purpose (cited from Starck, 2008) [16]. So we can see freedom of will aspect is related to will to meaning aspect. And there's also relation between will to meaning and meaning of life aspect, because life meaning is defined by the level of how a person is into fulfilling his/her own life(Hartman \& Zimberoff, 2003) [35].

\section{Test of Initial Model}

After relevant analysis of Pearson's product-moment correlation, we confirmed that three latent variables and total marks have significant correlations, we processed CFA. The test result is:

On the overall fit of initial model, $\chi^{2}=613.23, d f=167, p$ $=.00, \mathrm{RMSEA}=.08, \mathrm{AGFI}=.85, \mathrm{TLI}=.90, \mathrm{CFI}=.91$. Among them $\chi^{2}$ reached a significant level but did not meet standard. However RMSEA met the standard under .10, and three indexes such as TLI and CFI met standard above .90; $\mathrm{AGFI}=.85$, and this does not meet the standard above.90, In accordance with Anderson and Gerbing (1984) [36], they claimed that the acceptable value only needs to be AGFI $\geq 0.80$. In short, this result shows that the initial model is appropriate.

From the factor loading among all observing indicators, the factor loading of FM 6 is .48 and FM 7 is .43. Bogozzi and $\mathrm{Yi}(1988)$ [37] purposed that, the factor loading between latent variables and indicators should be between .50-.90. And only when is $\geqq .71$, the inner quality of such model will be better. Tabachnica and Fidell(2007) [38] believe when $\lambda$ is $\geq .55$, it can be called "well". Moreover, Bollen (1989) [39] advocated that there has to be at least three items for each factor, 5-7 items will be the best. This study has to take care of the fit, inner quality and numbers of items of overall model. Taken $\lambda \geq .55$ proposed by Tabachnica and Fidell as a standard, we then cancel two items such as FM 6 and 7.

\section{Challenge of Modified Model}

The model after deleting items such as FM6 and 7 is called a modified model. The results of analyzing this modified model are the followings (See Fig.1.):

The results of overall fit include: $\chi^{2}=495.59, d f=132, p$ $=.00, \mathrm{RMSEA}=.08, \mathrm{AGFI}=.85, \mathrm{TLI}=.91, \mathrm{CFI}=.92$. From the index of overall fit, RMSEA, TLI and CFI have met the standard. $\chi^{2}$ has met a significant level but not met the standard yet, so its value is easy to get affected by the number of sample as just a reference. As to the result AGFI $=.85$, and it fit the assumption of Anderson and Gerbing (1984) [36]. So based on above analysis, the modified model is fit. 


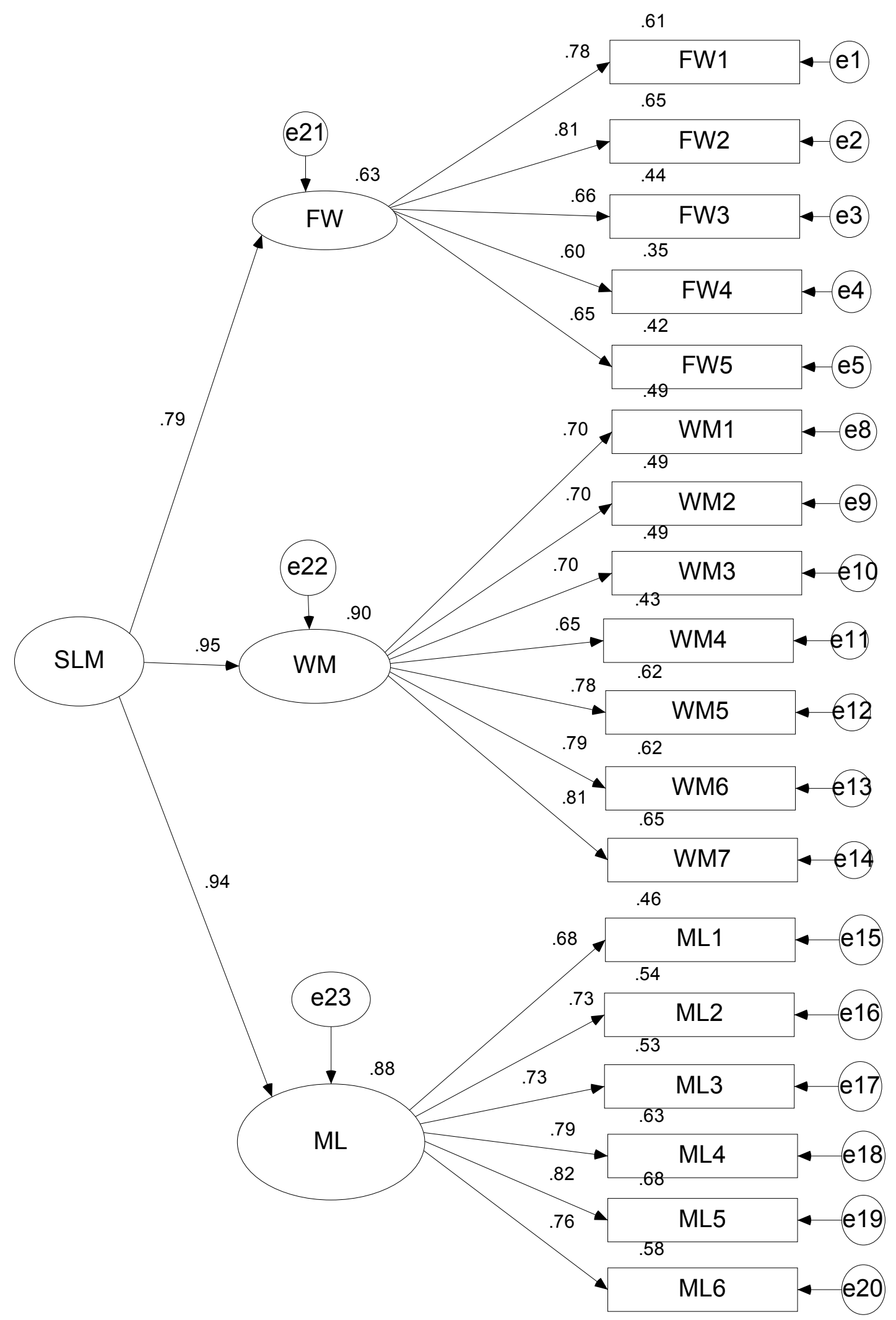

Note: The Value of measurement indicators indicates individual reliability

Figure 1. goodness-of-fit of modified model (standard estimate) 
Table 5. The Abstract of life meaning sense scale construct discrimination

\begin{tabular}{cccccccc}
\hline \multirow{2}{*}{ Match Latent Factor } & \multicolumn{3}{c}{ Limited Model(B) } & & Unlimited Model(A) & $\begin{array}{c}\chi^{2} \text { difference } \\
\text { (B-A) }\end{array}$ \\
\cline { 2 - 8 } & $\rho_{1}$ & $d f$ & $\chi^{2}$ & $\rho$ & $d f$ & $\chi^{2}$ & $\Delta \chi^{2}$ \\
\hline $\begin{array}{c}\text { Will Freedom-Will for purchasing } \\
\text { Meaning }\end{array}$ & 1 & 54 & 322.56 & .36 & 53 & 223.89 & $88.67^{*}$ \\
\hline $\begin{array}{c}\text { Will for Purchasing Meaning-Life } \\
\text { Meaning }\end{array}$ & 1 & 65 & 446.22 & .35 & 64 & 352.20 & $94.05^{*}$ \\
\hline Will Freedom-Life Meaning & 1 & 44 & 251.65 & .30 & 43 & 135.65 & $116.00^{*}$ \\
\hline
\end{tabular}

Note: *means the difference among Chi-square values for limited model and unlimited model are more than 3.84, and meet the significant level of .05.

\section{Preliminary Evaluation on Basic Fitness}

Based on the result of modified model, we processed a preliminary evaluation for basic fitness, and discover below. The result is as Table.5 : 1.) In the element of matrix $\Theta_{\varepsilon}$, the tolerant variances from $\varepsilon_{1}$ to $\varepsilon_{20}$ are all positive. 2. )The $t$ values for all tolerant variances are from 10.49 to 14.25 and met the significant level above .001. 3.) Parameter standard errors are from .06 to .10, there is not a big one. 4.) Latent variables and the factor loading $\lambda 1-\lambda 20$ among its measurement indicators are from .68 to .90 . And this meets the standard to be more than .50 and less than .95 .

Based on above analysis, the test result has met the assumption, so it means the basic fitness is a good one. Therefore, there is no offending estimate (And it means all output data are in an acceptable range).

Analysis of Inner Construction Fitness

Individual Reliability

Individual reliability is the square of the factor loading for observing indicator, and there are eighteen items for observing indicators, such as $\lambda 1-\lambda 20$ in the table ( $\lambda 6$ and $\lambda 7$ were deleted), and the individual reliability is between .42 to .68 .

\section{Component Reliability}

As to the component reliability for latent variables, the component reliability for three latent variables are the followings: for the freedom of will is .83 , for the will to meaning is .83 and mean of life is .89 . These three latent variables are all more than .60 , that being said, the measurement standard for three latent variables can reach a latent construct which is more than $83 \%$. In another words, three latent variables in this study has a basic stability when it reflects the proper fraction.

\section{Average Variance Extracted}

As to the average variance extracted $(\rho v)$ for the three latent variances, the freedom of will is .50 , the will to meaning is .54 and the mean of life is .57 . The three latent variables are all above the standard of .50, so this means the observing variables can sufficiently reflect the latent variables it constructed.

Construct Discrimination
As to the construct discrimination for verifying the latent variables, this study adopted the comparison between competitive models (Anderson \& Gerbing, 1988) [36]. From Table.5, we see that: the difference among Chi-square values for three limited models and unlimited models respectively are $88.67,94.05,116.00$. They are all more than $3.84(p$ $<.05$ ), the critical indicator. It shows the difference among Chi-square values among three limited models and unlimited models has met the significant level of .05. The assumption that the correlation between any two paired latent variables are completely correlative $(\rho=1)$ cannot be proved. The three latent variables (factor construct) in the table means the latent traits it shows has significant difference.

\section{Measurement Invariance test}

There are two phases for measurement invariance test, the first one is the overall model of entire body and each group, when it reaches the fitness it is thus allowed to enter the second phase. This study respectively tests three models such as overall body, male and female. The outcome shows the freedom of the three models are the same, and it shows the setting factor constructs are totally equal. From the aspect of $\chi^{2}$, all the three groups met the significant level, but from the aspect of RMSEA, AGFI, TLI and CFI, the model of overall body will be the best. From the aspect of fitness standard mentioned previously, the results for three models can be accepted, therefore we went to the second phase as the across samples analysis.

In the second phase, as to the choosing of model to test measurement invariance, Tabachnick and Fidell(2001) [38] believed that as long as there are equality for parameters such as factor loading between groups and factor covariance, the measurement model has the invariance; and that being said, we can claim that data from every group is from the same population. For this point of view, there are three models for research: Model 1: baseline model, it means across samples there is no assumption for invariance equality, if it goes to factor construction the assumptions are equal. Model 2: measurement weights model, assuming the factor loading for both male and female groups are the same. Model 3: the identical models such as factor loading and factor covariance, we can further assume that the covariance for assumed factor has the invariance across population.

From the result of our test we found that the $\Delta \chi^{2}$ did not meet a significant level, and the absolute value for $\Delta$ NFI, 
$\triangle \mathrm{IFI}, \triangle \mathrm{RFI}$ and $\triangle \mathrm{TLI}$ are less than .05 , it proves the assumption of equality. It means there is invariance in the modified model in the groups of males and females, and it suggests that this scale can be applied to both male and female students in university.

Table 6. Abstract of measurement invariance test

\begin{tabular}{|c|c|c|c|c|c|c|c|}
\hline Model & $d f$ & $\chi^{2}$ & $p$ & RMSEA & AGFI & TLI & CFI \\
\hline \multicolumn{8}{|c|}{ Phase 1} \\
\hline Overall & 132 & 495.59 & .00 & .08 & .85 & .91 & .92 \\
\hline Male & 132 & 271.92 & .00 & .09 & .78 & .91 & .92 \\
\hline \multirow[t]{2}{*}{ Femal } & 132 & 417.21 & .00 & .08 & .82 & .89 & .91 \\
\hline & $\Delta d f$ & $\Delta \chi^{2}$ & $p$ & $\Delta \mathrm{NFI}$ & $\Delta \mathrm{IFI}$ & $\Delta \mathrm{RFI}$ & $\Delta \mathrm{TLI}$ \\
\hline \multicolumn{8}{|c|}{ Phase 2} \\
\hline \multicolumn{8}{|c|}{ Assuming model Unconstrained to be correct) } \\
\hline $\begin{array}{c}\text { Model } \\
2\end{array}$ & 14 & 19.31 & .15 & .004 & .004 & -.004 & -.004 \\
\hline $\begin{array}{c}\text { Model } \\
3\end{array}$ & 15 & 22.40 & .10 & .004 & .005 & -.004 & -.004 \\
\hline \multicolumn{8}{|c|}{ Assuming model 2 to be correct } \\
\hline $\begin{array}{c}\text { Model } \\
3 \\
\end{array}$ & 1 & 3.09 & .08 & .001 & .001 & .000 & .000 \\
\hline
\end{tabular}

The Challenge of Model Fit by Cross-validation

Since the model has been modified, it needs another batch of samples $(N=405)$ to again verify the modified model. The result of analysis is : the overall fitness is as the followings: $\chi^{2}=526.12, d f=132, p=.00, \mathrm{RMSEA}=.09, \mathrm{AGFI}=.83$, $\mathrm{TLI}=.90, \mathrm{CFI}=.92$. As to the index of overall fitness, RMSEA, TLI and CFI met the standard. $\chi^{2}$ has reach the significant level but not standard, and AGFI $=.85$; but Anderson and Gerbing(1984) [36] claimed that AGFI $\geq 0.80$ is okay. Based on above analysis, the model fit by cross-validation is fit.

\section{Discussion}

This study aims to develop the life meaning scale for university students. The process of development was, in the beginning we read relevant literatures, adopted the three beliefs in Frankl's logotherapy such as freedom of will, will to meaning and life meaning as the foundation and proposed our first draft based on referring to relevant scales. In this phase, we proposed a first draft which has twenty items for three factors.

After discussing the first draft with three university students item by item and decorating the literal description for the item, it was taken to be the pre-examination questionnaire.

Second, based on the result of literature analysis, the three factors that include twenty items are the initial models. Since the three major beliefs of logotherapy can directly be assigned as the factors and they are correlated to each other, therefore we directly adapted the two-level single factor model to process the $\mathrm{CFA}(N=466)$.
The test result shows, the overall initial model is fit, but the observing indicators the factor loading of FM6 and FM7 are .48 and .43 which did not meet the standard .50 to .95 proposed by Bogozzi and Yi(1988) [37] and the $\lambda \geqq .55$ standard believed by Tabachnica and Fidell(2007) [38]. Therefore we deleted the two items, the first one of two items is "Will I be guilty or condemning myself if I haven't done a thing appropriately?"; perhaps due to most objects could handle their educational and club activities, so since they could handle them well, they did not feel guilty as unable to understand the meaning of this question. As to another of two items, "Do I accept death since death is a part of life?", perhaps their experiences about death were too few and they are still too young with much vitality to seriously think about death.

Third, we deleted factors FM6 and FM7, there were twenty items among three factors and that became eighteen items in there; the latter is called the modified model.

If we verify it with CFA again, we will find that, the overall fitness is acceptable, and the basic fitness is good while the fitness analysis of inner construction is appropriate. In short, the life meaning scale to represent eighteen items among three factors is very stable.

The eighteen items respectively are: 5 items about freedom of will, 7 items about pursuing meaning, 6 items about life meaning, and the quantity of items meet Bollen(1989) [39]'s revealing that the best proportion of each factor is 5-7 items per factor.

Fourth, we categorized university students' genders as groups via modified model to process measuring invariance. It turned out that $\Delta \chi^{2}$ did not meet a significant level, and absolute values of $\Delta$ NFI, $\Delta \mathrm{IFI}, \Delta \mathrm{RFI}$ and $\Delta \mathrm{TLI}$ are less than .05 , where that means the assumption of invariance is true. It also shows there is invariance among modified models of this group, and that being said, this scale can be applicable to both male and female students in university.

Fifth, since the model has been modified, we need to use another batch of samples to test this modified model again, and this is called cross-validity model. The result shows the cross-validity model is fit, so it shows the scale developed in this study can be applied to different samples.

Concluding above results, on the way of developing scale in this study, we used many kinds of data to understand the reliability and validity of scale. The result turned out as we obtained eighteen items for the life meaning scale for university students, and the numbers of item are very similar to the 20 items in PIL test by Crumbaugh and Maholick (1964) [6], 20 items in Crumbaugh (1977) [22] 's SONG test, 21 items in life meaning scale by Jim (2006) [29] etc and 17 items in Swedish life purpose scale by Jonsén (2010) [30] etc.

The number of item in questionnaire does not matter, as long as you have reliability and validity which met the standard, it is fine; if there are too many items, it will affect samples' intentions of answering the items. 


\section{REFERENCES}

[1] G. T. Reker, Theoretical perspective, dimensions, and measurement of existential meaning. In G. T. Reker \& K. Chamberlain (Eds.), Exploring existential meaning: Optimizing human development across the life span (pp. 39-55). Thousand Oaks, CA: Sage, 2000.

[2] J. G. Dezutter, A. S. Waterman, S. J. Schwartz, K. Luyckx, W. Beyers, A. Meca, S. Y. Kim, S. K. Whitbourne, B. L. Zamboanga, R. M. Lee, S. A. Hardy, L. F. Forthun, R. A. Ritchie, R. S. Weisskirch, E. J. Brown, S. J. Caraway, Meaning in life in emerging adulthood: A person - oriented approach. Journal of personality, Vol, 82, No. 1, 57-68, 2014.

[3] A. Waytz, H. E. Hershfield, D. I. Tamir, D. I. Mental simulation and meaning in life, Journal of personality and social psychology, Vol: 108, No. 2, 336-351, 2015.

[4] M. Csíkszentmihályi, Flow: The psychology of optimal experience. New York, NY: Harper and Row, 2008.

[5] V. E. Frankl, Man's search for meaning: An introduction to logotherapy. New York, NY: Simon \& Schuster, 1984.

[6] J. C. Crumbaugh, J. C., L. T. Maholick L.T. Manual of Instructions for the Purpose-in-Life Test. Lafayette, IN: Psychometric Affiliates, 1964.

[7] Y. C. Ho, College students' meaning of life and its correlates: An empirical study of the concept of logotherapy. Bulletin of Educational Psychology, Vol, 20, 87-106, 1987.

[8] Y. C. Ho, The life attitude profile: A study of reliability and validity. Bulletin of Taiwan Normal University, Vol, 35, 71-94, 1990.

[9] W. B. Gould, Viktor E. Frankl: Life with meaning. Belmont, CA Brooks/Cole, 1993.

[10] G. Corey, Theory and practice of counselling and psychotherapy (9th ed.). Belmont, CA: Brooks/Cole, 2012.

[11] V. E. Frankl, The doctor and the soul. New York, NY: Bantam, 1967.

[12] V. E. Frankl, The will to meaning: Foundations and applications of logotherapy (2nd ed.). New York, NY: New American Library, 1988.

[13] V. E. Frankl, The will to meaning. New York, NY: New American Library, 1967.

[14] P. L. Starck, The human spirit: The search for meaning and purpose through suffering. Human Medicine Health Care, Vol: 8, No. 2, 2008. Retrieved September 14, 2014 from http://www.humanehealthcare.com/Article.asp?art_id=811

[15] P. T. P. Wong, G. T. Reker, G. Gesser, Death Attitude Profile-Revised: A multidimensional measure of attitudes toward death. In Neimeyer, R. A. (Ed.), Death anxiety handbook: Research, instrumentation, and application(pp. 121-148). Abingdon, England: Taylor \& Francis, 1994.

[16] P. L. Starck (2008). Theory of meaning. In M. J. Smith \& P. R. Liehr(Eds.), Middle range theory for nursing(2nd ed., pp. 85-103). New York, NY: Springer, 2008.

[17] V. E. Frankl, The doctor and the soul: From psychotherapy to logotherapy. New York: Vintage Books, 1986.

[18] W. Breitbart, Spirituality and meaning in supportive care:
Spirituality- and meaning-centered group psychotherapy interventions in advanced cancer. Supportive Care in Cancer. New York, NY: Spriner-Verlag, 2001. Doi:10.1007/s00 5200100289

[19] S. E. Schulenberg, A. M. Melton, A confirmatory factor-analytic evaluation of the Purpose in Life Test: Preliminary psychometric support for a replicable two-factor model. Journal of Happiness Studies, Vol: 11, No. 1, 95-111, 2010 .

[20] J. Battista, R. Almond, The development of Meaning in Life, Psychiatry, Vol: 36, 409-427, 1973.

[21] M. F. Steger, P. Frazier, S. Oishi \& M. Kaler, The Meaning in Life Questionnaire: Assessing the presence of and search for meaning in life. Journal of Counselling Psychology, Vol: 53, No. 1, 80-93, 2006.

[22] J. C. Crumbaugh, Manual of instructions: The Seeking of Noetic Goals test (SONG). Abilene, TX: Viktor Frankl Institute of Logotherapy, 1977.

[23] R. R. Hutzell, Seeking of Noetic Goals test. In D. J. Keyser \& R. C. Sweetland (Eds.), Test critiques, Vol: 6, 486-490, Kansas, MO: Test Corporation of America, 1987.

[24] R. Hablas, R. Hutzell, The Life Purpose Questionnaire: An alternative to the Purpose in Life test for geriatric, neuropsychiatric patients. In S. A. Wawrytko (Ed.), Analectica Frankliana: The proceedings of the First World Congress of Logotherapy (pp. 211-215). Berkeley, CA: Strawberry Hill, 1980.

[25] G. T. Reker, E. J. Peacock, The Life Attitude Profile (LAP); A multidimensional instrument for assessing attitudes toward life. Canadian Journal of Behavioral Science, Vol: 13, 264273, 1981.

[26] P. L. Starck, Guidelines-Meaning in Suffering Test. Abilene, TX: Viktor Frankl Institute of Logotherapy, 1985.

[27] D. T. L. Shek, Reliability and factorial structure of the Chinese version of the Purpose in Life Questionnaire. Journal of Clinical Psychology, Vol: 44, 384-392, 1988.

[28] P. T. P. Wong, Implicit theories of meaningful life and the development of the Personal Meaning Profile. In P .T .P. Wong \& P. S. Fry (Eds.), The human quest for meaning: A handbook of psychological research and clinical application (pp. 111-140). Mahwah, NJ: Lawrence Erlbaum, 1998.

[29] H. S. Jim, J. Q. Purnell, S. A. Richardson, D, Golden-Kreutz, B. L. Andersen, Measuring meaning in life following cancer, Quality of Life Research, 15, 1355-1371, 2006. DOl:10/1007s11136-006-0028-6

[30] E. Jonsén, L. FagerstrÖm, B. Lundman, B. Nygren, M. Vähäkangas, G. Strandberg, G, Psychometric properties of the Swedish version of the Purpose in Life scale. Scandinavian Journal of Caring Sciences, Vol: 24, No,1, 41-48, 2010. doi: 10.1111/j.1471-6712.2008.00682.x

[31] B. M. Law, Psychometric properties of the existence subscale of the Purpose in Life questionnaire for Chinese adolescents in Hong Kong. The Scientific World Journal, 1-5, 2012.

[32] S. R. Dirksen, Search for meaning in long-term cancer survivors. Journal of Advanced Nursing, Vol: 21, 628-633, 1995.

[33] H. T. Wu, The development and construct validity of Teacher' 
Sense of Life Meaning Scale. Journal of Theory and Practice, Vol: 29, 91-122, 2014.

[34] T. D. Little, Mean and covariance structures (MACS) analysis of cross-cultural data: Practice and theoretical issue. Multivariate Behavioral Research, Vol, 32, 53-76, 1997.

[35] D. Hartman, D. Zimberoff, The existential approach in heart-centered therapies. Journal of Heart-Centered Therapies, Vol: 6, No. 1, 3-4, 2003.

[36] J. C. Anderson, D. W. Gerbing, The effect of sampling error on convergence, improper solutions and goodness-of-fit indices for maximum likelihood confirmatory factor analysis, Psychometrika Vol:49, 155-173, 1984.

[37] R. P. Bagozzi, Y. Yi, On the evaluation of structural equation models. Academic of Marketing Science, Vol: 16, 74-94, 1988. DOI: 10.1007/BF02723327

[38] B. G. Tabachnick, L. S. Fidell, Using multivariate statistics (5th Ed.) Needham Heights, MA: Allyn and Bacon, 2007

[39] K. A. Bollen, Structural equations with latent variables. New York, NY: Wiley \& Sons, 1989. 